\title{
The Effect of Individual Characteristics, Competence and Quality of Work Life On Work Motivation, Intention to Leave and Employee Performance Outsoursing Manufacturing Company in East Java Province
}

\author{
Dr. Sumantri, SE,MM \\ Doctor from University of 17 Agustus 1945 Surabaya \\ Prof. Dr.Hj. Brahmasari, drg, Dipl, DHE, MPA \\ Lecturer from University of 17 Agustus 1945 Surabaya \\ Dr.Hj. Mujanah, MBA \\ Lecturer from University of 17 Agustus 1945 Surabaya
}

\begin{abstract}
The existing regulations are not yet adequate to regulate the outsourcing that has been running in the middle of economic life. This condition affects workers labor/looked at as an object that can be exploited. Outsourcing problems in Indonesia is getting worse along with the practice of outsourcing has been legalised by the Government with the Act No. 13 of 2003 On Labor that much controversy it. This research aims to demonstrate and analyze the influence of individual characteristics, competence, quality of work life against motivation, intention to leave and employee performance employee outsoursing outsourcing manufacturing company in East Java province. The population in the research this is the employee outsourcing manufacturing company in East Java province totaled 774 people and the sample numbered 264 people. Method of data processing is using SEM (Equational Structure Modeling) with AMOS version 18. The result of discussions can be concluded that 1) Characteristics of the individual significant effect on work motivation, 2) Characteristics of the individual significant effect on competency, 3) Characteristics of the individual significant effect on intention to leave, 4) Characteristics of the individual no significant effect on the employee performance, 5) Competence significant effect on work motivation, 6) Competence significant effect on intention to leave, 7) Competence significant effect on to the employee performance, 8) Quality of work life significant effect on work motivation, 9) Quality of work life significant effect on intention to leave, 10) Quality of work life significant effect on the employee performance, 11) Work motivation significant effect on intention to leave, 12) Work Motivation significant effect on the employee performance and 13) Intention to leave no significant effect on the employee performance.
\end{abstract}

Keywords: individual characteristics, competence, quality of work life, work motivation, intention to leave and employee performance

\section{INTRODUCTION}

A proliferation of outsourcing companies as service providers on one side has been menumbuh developed the corporate world as well as increasing government revenue from corporate tax side as well as create jobs to minimize the number of pengganguran. But on the other hand the presence of decreased levels of kesejahtraan employees of the company where employees work in manufacturing industries with a presence over the status to employees of the temporary and outsourced work based on PKWT. 
One of the efforts made by the company by applying a system of outsourcing is to enhance the effectiveness and efficiency of planning in human resources management, such as recruitment, training programs, administration personnel, retirement or succession program (Karthikeyan et al., 2011), and traditionally, the most important purpose of the system of outsourcing is increasing the cost-efficiency of effort (Holcomb and Hitt, 2007; Sutedi, 2009), and by using a system of outsourcing companies may be trying to save expenditure to finance the development of human resources (HR) company (Sutedi, 2009).

The current Government has set up a formal legally that the existence of the company-a provider of labor, especially the manufacturing industry who submit partial execution of the work to other companies through the provision of work or chartering agreement workers/labourers are made in writing in accordance with the provisions of article 64 of law No. 13/2003. The implementation of such understanding is called outsourcing in accordance with the ruling of the Constitutional Court No. 27/PUU-IX/2011.

Manufacturing companies to facilitate the supervision of the use of outsourcing employees. Outsourced employees into a performance measure when the production output has been determined by the company. With regard to the performance of employees, there are several factors that affects the performance of the employee. Individual characteristics, competence and quality of work life presents to affect the performance of the employees. Some research results have confirmed that the third non variable effect on the performance of employees like Jakfar (2014) and Pujiwati and Susanty (2015). Other factors that also affect the performance of the employee was the motivation and intention to leave. Some research results have been justifying the second variable hardness, affect the performance of the employee such as Arifin (2015). Based on the above description, then the researcher is interested in researching with the title "the influence of Individual Characteristics, competence and quality of work life against Motivation, intention to leave and Employee Performance Outsoursing manufacturing company in East Java province.

\section{Individual characteristics}

\section{LITERATURE REVIEW AND HYPOTHESIS}

Stoner (1989:431) individual characteristics i.e., interests, attitudes and needs of someone who was brought into the work situation. Mathis and Jackson (2006:35) are four individual characteristics that affect how people can be accomplished include interest, identity, personality and social background. Robbins (2008:171) individual characteristics is the attitude indicator is the evaluative statements either desired or undesired objects, people or events. Personality is a set of characters that underlie behavior patterns are relatively stable in responding to an idea, object, or a person in their environment.

\section{Competence}

Spencer and Spencer (1993:9) Competence is an ability to perform or do a job or task that is based upon skills and knowledge as well as supported by the attitude of work required by the job. Gordon (1996) some aspects contained in the concept of competency as follows: i.e. knowledge, understanding, skill, value, attitude and interest.

\section{The quality of working life}

Wayne (2003), that managers provide opportunities for workers to design their work about what is needed in making a product or service so that they can work effectively. Walton (1974) to measure the quality of working life: a fair and adequate compensation, a safe and healthy 
environment, growth and security, the development of capabilities, total living space, constitutionalism, social integration, and social relevance.

\section{Work Motivation}

Robbins (2008) motivation of working is beyond uproses that generates an intensity, direction and individual perseverance in trying to achieve a goal. Herzberg (1966) motif is the motivation of working encourages employees to do the work of appropriate basic tasks and functions of the Office are assessed or measured on the basis of the dimensions of the motivators and hygiene factors. In the absence of motivation of employees to cooperate for the benefit of the company, then the intended purpose will not be achieved. According to the theory of motivation theory McClelland as expressed by Robbin (2011:207) then work motivation indicator consists of several aspects needs i.e. the need for achievement, the need for affiliation, and the need for power.

\section{Intention to leave}

Intent to leave is of interest to resign voluntarily or otherwise permanently from an organization (Robbins, 2007:38). Intent to leave a person's subjective possibility is to display an act of Fisbein and Ajzen (1975:301). The level of intent to leave the high can lead to increased costs recruitmen, selection, and training. Ableson (2013) interpret the intent to leave as the desire for someone to move and look for an alternative place of work to another. Intention to leave is measured using indicators (Mor Barak, Nissli, and Levin: 2001) include: demographic, organizational commitment and satisfaction and fairness in providing compensation and organizational culture.

\section{Employee Performance}

Gibson (2004) employee performance is the result of a person's behavior or group associated with the way it works. States that the performance is basically what is done or not done employees. Operationally performance is measured using indicators (Anoraga (2005:178-179) that motivation, education, discipline, skill, attitude to work ethic, nutrition and health, level of earnings, work environment, physical noin technology, means of production, the necessary means of production factors, social security, management and opportunity achievers 


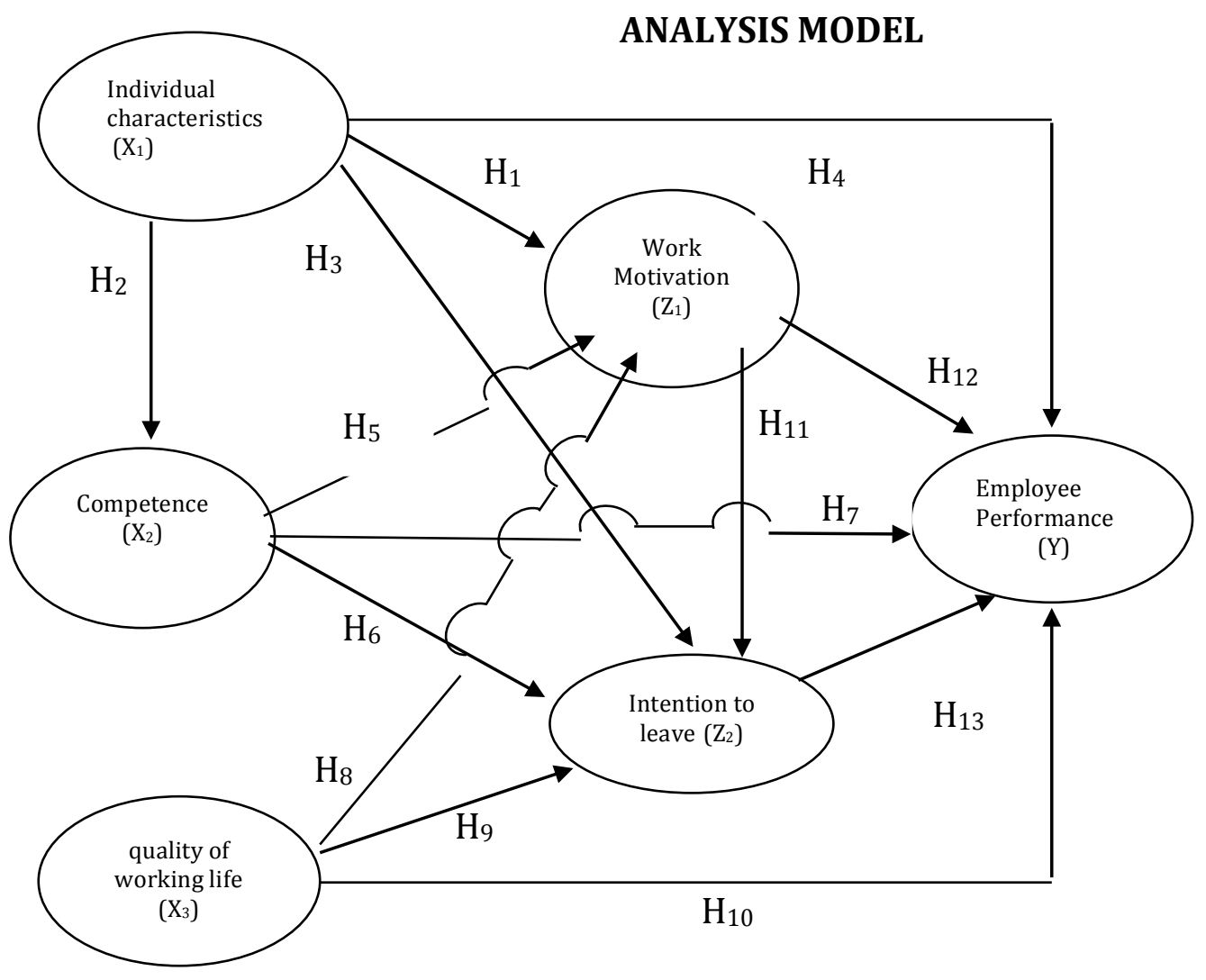

Figure 1. Analysis Model

RESEARCH METHODS

The population in this research is outsourced employees totalling 774 people are scattered in 5 (five) manufacturing company in East Java province. The number of samples obtained on the basis of 264 reference formula Yamane (Narimawati and Munandar, 2008). Measurement techniques questionnaire using likert scale. This research uses of data analysis in SEM (Equational Structure Modeling) using the AMOS version 18 (Ferdinand, 2000:6). 


\section{ANALYSIS AND DISCUSSION}

Results analysis using SEM research model shown in Figure 1. A model is said to be good in the development of the conceptual and theoretical hypothesis supported by empirical data, structural equation model test results are shown on the following picture:

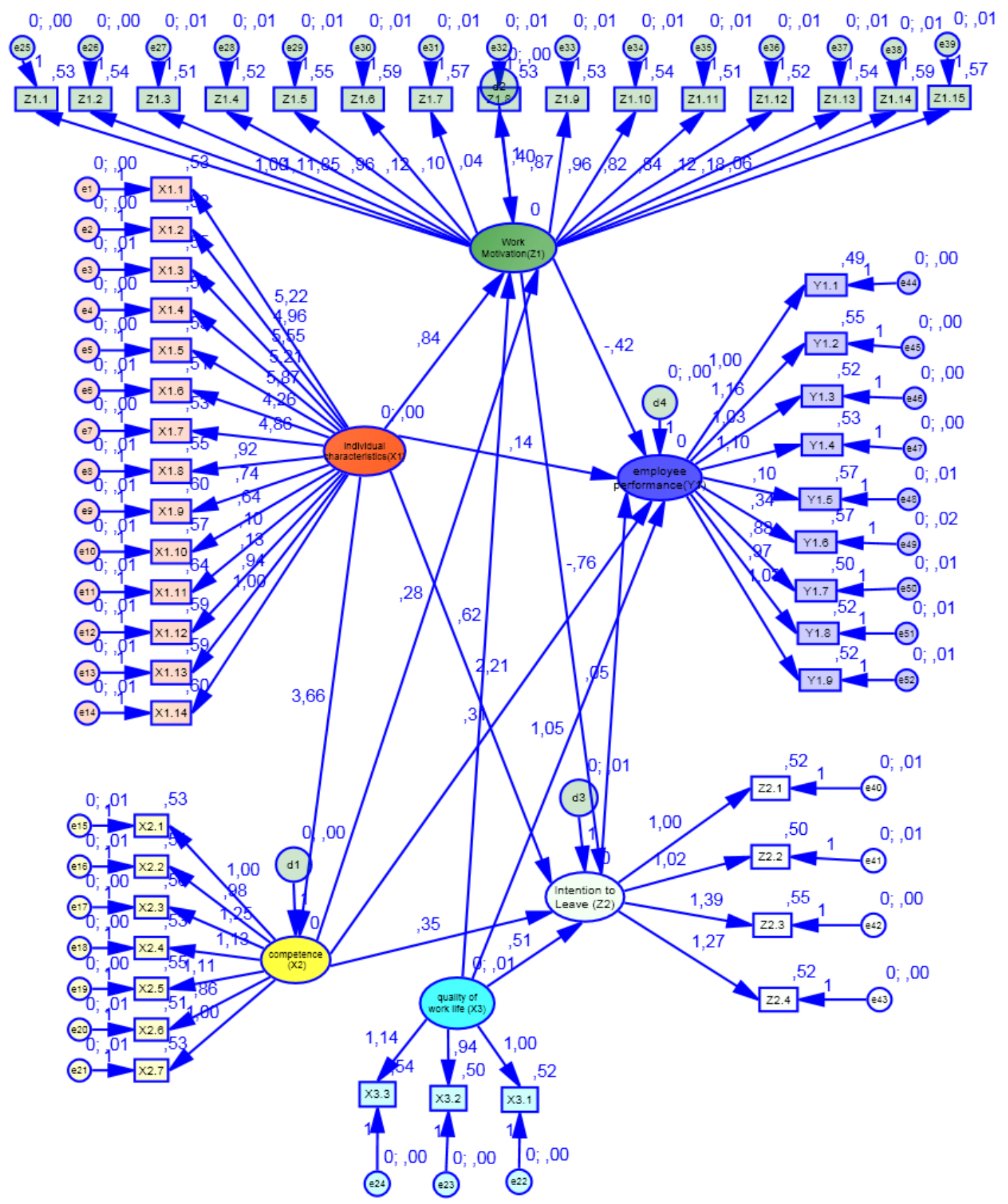

Figure 2. Structural Equation model

The table below is a table of the results of tests of Goodness of Fit of the model taken from the last modified or the results of the development model of the best mods. The results of calculation of index of conformity (goodness of fit index) show that of the eight criteria are evaluated it turns out only two criteria that already meet (fit) i.e. the Goodness of Index (GFI) and RMR. 
Tabel 1. Indeks Kesesuaian Model Pada Structural Model

\begin{tabular}{|l|c|c|c|}
\hline \multicolumn{1}{|c|}{ Goodness of Fit Measure } & Indeks & Cut off & Keterangan \\
\hline Chi-square of estimate model & 89,055 & & \\
\hline Probability Level & 0,000 & $>0,05$ & Tidak Fit model \\
\hline Goodness of Index (GFI) & 0,929 & $\geq 0,9$ & Fit model \\
\hline Adjusted Goodness of Index (AGFI) & 0,725 & $\geq 0,9$ & Tidak Fit model \\
\hline RMSEA & 0,110 & $\leq 0,08$ & Tidak Fit model \\
\hline RMR & 0,041 & $\leq 0,05$ & Fit model \\
\hline Tucker-Lewis Index (TLI) & 0,670 & $\geq 0,9$ & Tidak Fit model \\
\hline Comparative Fit Index (CFI) & 0,686 & $\geq 0,9$ & Tidak Fit model \\
\hline
\end{tabular}

Testing the hypothesis presented in this study was done based on the value of the Critical ratio of CR from a relationship of causality. The results of the analysis of the relationship of causality between the variables research using program AMOS version 6 can be seen in table 2 .

Keywords: individual characteristics, competence, quality of work life, work motivation, intention to leave and employee performance

Tabel 2.Uji Kausalitas Regression Weight

\begin{tabular}{|c|c|c|c|c|c|c|}
\hline \multicolumn{3}{|c|}{ Hubungan Kausalitas } & \multirow{2}{*}{$\begin{array}{l}\begin{array}{l}\text { Std. } \\
\text { Est. }\end{array} \\
, 807\end{array}$} & \multirow{2}{*}{$\begin{array}{l}\text { SE } \\
338\end{array}$} & \multirow{2}{*}{$\frac{\text { CR }}{2,391}$} & \multirow{2}{*}{$\begin{array}{c}\begin{array}{c}\text { Significa } \\
\text { nt }\end{array} \\
, 017\end{array}$} \\
\hline $\begin{array}{l}\text { individual } \\
\text { characteristics }\end{array}$ & $\rightarrow$ & work motivation & & & & \\
\hline $\begin{array}{l}\text { individual } \\
\text { characteristics }\end{array}$ & $\rightarrow$ & competence & 3,663 & $\begin{array}{r}1,20 \\
5\end{array}$ & 3,039 & ,002 \\
\hline $\begin{array}{l}\text { individual } \\
\text { characteristics }\end{array}$ & $\rightarrow$ & Intention to_Leave & ,276 & , 047 & 2,614 & ,009 \\
\hline $\begin{array}{l}\text { individual } \\
\text { characteristics }\end{array}$ & $\rightarrow$ & $\begin{array}{l}\text { employee } \\
\text { performance }\end{array}$ & ,662 & 041 & 1,792 & ,073 \\
\hline competence & $\rightarrow$ & work motivation & 2,491 & ,953 & 5,856 & $* * *$ \\
\hline competence & $\rightarrow$ & Intention to_Leave &, 450 & ,133 & 3,386 & $* * *$ \\
\hline competence & $\rightarrow$ & $\begin{array}{l}\text { employee } \\
\text { performance }\end{array}$ & ,803 & ,242 & 5,436 & $* * *$ \\
\hline quality of work life & $\rightarrow$ & work motivation & $-1,139$ & 348 & $\begin{array}{r}16,15 \\
1\end{array}$ & $* * *$ \\
\hline quality of work life & $\rightarrow$ & Intention to_Leave & ,904 & ,504 & 3,314 & $* * *$ \\
\hline quality of work life & $\rightarrow$ & $\begin{array}{l}\text { employee } \\
\text { performance }\end{array}$ & ,536 & ,099 & 9,881 & $* * *$ \\
\hline work motivation & $\rightarrow$ & Intention to_Leave & 1,638 & ,166 & $-3,273$ & ,001 \\
\hline work motivation & $\rightarrow$ & $\begin{array}{l}\text { employee } \\
\text { performance }\end{array}$ &,- 052 & ,062 & $-5,351$ & $* * *$ \\
\hline Intention to Leave & $\rightarrow$ & $\begin{array}{l}\text { employee } \\
\text { performance }\end{array}$ & $-1,215$ & ,227 &,- 837 & ,403 \\
\hline
\end{tabular}

\section{The characteristics of individual significant effect on work motivation}

The results of the variable parameter estimation characteristics of individuals towards work motivation based on indicators-charge indicators will show significant results with a value of 
CR $2.391(<1.96)$ and extent of 0.017 significance $(p 0.05<)$ shows that the characteristics of the individual effect significantly to the motivation of working proved his righteousness. Results of the research it supports research conducted by Jakfar (2006) concludes that the characteristics of the individual effect significantly to the motivation of work. this research results prove that the theory of Stoner (1989) is an interest, attitudes and needs of someone who was brought into the work motivation it is very important to increase the outsourced employee motivation in the company

\section{The characteristics of Individual significant effect on Competency}

Results variable parameter estimation of characteristics of the individual against the competencies based on indicators-charge indicators will show significant results with a value of CR $3.039(<1.96)$ and 0.002 significance level (p $0.05<$ ) shows that the characteristics of the individual effect significantly to proven competencies. Results of the research it supports research conducted by Sarwoko, Surachman, Armanu, and Hadiwidjojo (2013) which concluded that individual characteristics influence on competence.

\section{The characteristics of Individual significant effect on Intention to leave}

Results variable parameter estimation Results characteristics of the individual against the intention to leave based on indicators-charge indicators will show significant results with a value of CR $2.614(<1.96)$ significance level 0.009 (p $0.05<$ ) shows that the characteristics of the individual effect is significant against the intention to leave proved his righteousness. Results of the research it supports research conducted by Tominaga (2013) which concluded that the characteristics of the individual effect is significant the intention to leave the research supporting the theory.

\section{The characteristics of Individual significant effect on the employee performance}

Results variable parameter estimation Results of individual characteristics on performance of employees based on indicators-charge indicators will show results that are not significant to the value of CR 1.792 ( $>1.96$ ) significance level 0.073 (p $0.05>$ ) shows that the characteristics of the individual effect significantly to the performance of the employee was denied the truth. The results of this study contradicts research conducted by Ul-haq and Rehman (2015) which concludes that the characteristics of the individual effect significantly to the employee performance.

\section{Competence significant effect on work motivation}

Results variable parameter estimation competence Results against the indicators based on the motivation of working-charge indicators will show significant results with a value of CR (5.856 1.96) with adequate < significance 0000 (p $0.05<$ ) shows that the characteristics of the individual effect significantly to performance proven truth. Results of the research it supports research conducted by Murgianto, Sulasmi and Suhermin (2016), which concluded that the competence of influential significantly to work motivation.

\section{Competence significant effect on intention to leave}

the variable parameter estimation Results of competence against the intention to leave based on indicators-charge indicators will show significant results with a value of CR 3.386. $(<1.96)$ and extent of significance 0.000 (p $0.05<$ ) shows that significant influential competency against the intention to leave proved his righteousness. Results of the research it supports research conducted Yousaf, Sanders and Yustantio (2016), which concluded that the competence of significant effect the intention to leave the research support. 


\section{Competence significant effect on the employee performance}

Results variable parameter estimation competence Results against performance indicators based on employee-charge indicators will show significant results with a value of CR 5.436 ( $<$ 1.96) and extent of significance 0.000 (p $0.05<$ ) shows that a significant effect on performance competence employees proven true. The Results of this study support the research conducted Syahrum, Brahmasari and Nugroho (2016) that concluded that the significant effect on performance competence employees.

\section{Quality of work life significant effect on work motivation}

the results of parameter estimation of the variable quality of work life indicators based on work motivation against-charge indicators will show significant results with a value of CR $16.151(<1.96)$ and extent of significance 0.000 (p $0.05<$ ) shows that the quality of work life effect significantly to the motivation of working proved his righteousness. Results of the research it supports research conducted and Brahmasari Kurniawan, Ratih (2016) that concluded that the significant effect on the employees performance.

\section{Quality of work life significant effect on Intension to leave}

Result parameter estimation of variable quality of working lives on intension to leave based on indicators-charge indicators will show significant results with a value of CR $3.314(<1.96)$ and extent of significance 0.000 ( $\mathrm{p} 0.05<$ ) shows that the quality of work life effect significantly to the intension to leave rejected truth. Results of the research it supports research conducted Aketch, Odera, Chepkuto and Okaka (2012) concluded that the quality of work life effect significantly to job motivation.

\section{Quality of work life significant effect on the employee performance}

Result parameter estimation of variable quality of work life employees based on performance indicators-charge indicators will show significant results with a value of CR (9.881 1.96) with adequate $<$ significance 0.000 ( p $0.05<$ ) shows that the quality of work life effect significantly to performance proven truth. Results of the research it supports research conducted, Hamid, Moselem Ghanbar, Alireza, Hossein and Alireza (2012) which concluded that the quality of work life of significant effect on intention to leave the research supporting the theory.

\section{The motivation of working significant effect on Intention to leave}

The motivation of working against the Intention to leave based on indicators-charge indicators will show significant results with a value of CR-3.273 $(<1.96)$ and degrees of significance of 0.001 ( $0.05<$ ) shows that significant influential work motivation against the Intention to leave proven truth. These results support research Qureshi (2013), which concluded that significant influential work motivation on performance of employees.

\section{The motivation of working significant effect on the employee performance}

the results of parameter estimation variables work motivation on performance indicators based on karyawam-charge indicators will show significant results with a value of CR-5.351 (< 1.96) and extent of significance 0.000 ( p $0.05<$ ) suggests that the motivation of working effect significantly to performance proven employees. Results of the research it supports research conducted by Arifin (2015) which concluded that motivation effect siginfikan on performance of employees. As such, owned a high motivation of employees in work will generate a high outsourcing employee performance also 


\section{Intention to leave significant effect on the employee performance}

variable parameter estimation results of the intention to leave on performance indicators based on karyawam-charge indicators will show results that are not significant to the value of CR-0.837 $(<1.96)$ and 0.403 significance level (p $0.05>$ ) indicates that intention to leave a significant effect on performance karyawam denied the truth. The results of this penelitin contrary to the research conducted by Rasool, Arzu, Hasan, Rafi, and Kashif (2013) are summed up the intention to leave no significant effect on employees performance.

\section{SUMMARY}

1. Characteristics of the individual significant effect on work motivation.

2. Characteristics of the individual significant effect on competency.

3. Characteristics of the individual significant effect on intention to leave.

4. Characteristics of the individual no significant effect on the employee performance.

5. Competence significant effect on work motivation.

6. Competence significant effect on intention to leave

7. Competence significant effect on to the employee performance

8. Quality of work life significant effect on work motivation.

9. Quality of work life significant effect on intention to leave

10. Quality of work life significant effect on the employee performance.

11. Work motivation significant effect on intention to leave

12. Work Motivation significant effect on the employee performance.

13. Intention to leave no significant effect on the employee performance.

\section{LIMITATIONS}

1. The time available for researchers to carry out research by spreading the now questionnaire to respondents for an employee on a business day, it is really time to collide with researchers because researchers carrying out lectures while working, making it difficult for researchers to meet employees faced with time limitations.

2. The employee's Understanding of outsourcing personnel management model still less so troublesome to fill in questionnaire research correctly and on time

3. Not all locations of companies use outsourcing employees is acceptable and allows researchers to undertake research, since the issue of outsourcing is still a problem that is very sensitive to developments in the business world and the competition of labor outsourcing service providers

4. Not all outsourced employees who work in manufacturing companies in East Java province obtain adequate welfare of its members. Then it is very possible the difference manufacturing company in East Java province each area in East Java will give different results, so that the results of this research can not completely generalizable

\section{BIBLIOGRAPHY}

Aketch, Odera, Chepkuto dan Okaka. 2012. Effects of Quality of Work Life on Job Performance: Theoretical Perspectives and Literature Review.Current Research Journal of Social Sciences 4(5): 383-388.

Anoraga, Pandji., 2004, Business of Managements. Jakarta: Rineka Cipta.

Arifin, H. M. 2015. The Influence of Competence, Motivation, and Organisational Culture to High School Teacher Job Satisfaction and Performance. International Education Studies; Vol. 8, No. 1.

Asim, M. 2013. Impact of Motivation on Employee Performance with Effect of Training: Specific to Education Sector of Pakistan. International Journal of Scientific and Research Publications, Volume 3, Issue 9, September.

David, Mc.Clelland,1985, Human Motivation.Illinois : Scott, Foresman \& Company

Ferdinand, A. 2000. Structural Education Modelling in research management. The first edition. Semarang: Universitas Diponegoro.

Gibson, Ivancevish, Donelly, 2004. Organizations Behaviour, Boston. 
Sumantri, Brahmasari, H., \& Mujanah, H. (2017). The Effect of Individual Characteristics, Competence and Quality of Work Life On Work Motivation, Intention to Leave and Employee Performance Outsoursing Manufacturing Company in East Java Province. Archives of Business Research, 5(5), 115-125.

Herzberg, F. 1966. Work and the nature of man. Cleveland, OH: World Publishing Company.

Holcomb, T. R., \& Hitt, M. A. (2007). Toward a Model of Strategic Outsourcing. Journal of Operations Management, 25 ( 2), 464-481.

Jakfar, A.Aziz. 2014. Influence of Individual Characteristics, Organizational Culture and Work Motivation to Satisfaction and Performance of Hand-Rolled Cigarette Workers at the Cigarette Industry in Madura. International Journal of Science and Research (IJSR) ISSN (Online): 2319-7064. Faculty of Agriculture, Trunojoyo University, Madura, Indonesia.

Kurniawan, Brahmasari dan Ratih. 2016. The Influence Of Organizational Culture, Task Complexity and, Competence On Job Satisfaction, Organizational Citizenship Behavior, and Nurse Performance Of Kodam VII/Wirabuana Sulawesi Indonesian National Army Hospital. International Journal of Business and Management Invention ISSN (Online): 2319 - 8028, Volume 5 Issue 1, January.

Mathis, R.L dan Jackson, J.H. 2006. Human Resource Management. Jakarta: Salemba Empat.

Mor Barak, M.; Nissly, J.; \& Levin, A. 2001. Antecedents to retention and turnover among child welfare, social work, and other human service employees: What can we learn from past research? A review and metanalysis. The Social Service Review, 75(4), 625-661

Musriha. 2013. The Impact of Individual Characteristics and Organization Culture on Performance and Career Development of Employees Case studies Five Star Hotel in Surabaya Indonesia. Journal of Business and Management (IOSR-JBM). Volume 14, Issue 3 (Nov. - Dec.

Narimawati, Umi dan Munandar, Dadang. 2008. Theory and practice of Sampling techniques Using SPSS 15. Yogyakarta: Gava Media.

Pemerintah Republik Indonesia. 2003. Undang-Undang Republik Indonesia Nomor 13 tentang Ketenagakerjaan. Jakarta (ID): Sekretariat Negara.

Pujiwati, A., dan Susanty, E., 2015. The Influence of Individual Characteristics on Organization Performance and Job Satisfaction. $2^{\text {th }}$ Conference in Busines, Accounting and Management.

Qureshi, Seema. 2013. The Relationship between Work Motivation, Burnout and Intention to Leave for the Middle Level Managers of Garment Industry (A Case Study of Indian Garment Industry). Business and Management Horizons, Vol. 1, No. 2.

Rasool, F., Arzu, F., Hasan, A., Rafi, A., and Kashif, A.R. 2013. Workplace Bullying and Intention to Leave: The Moderating Effect of the Organizational Commitment. Information Management and Business Review Vol. 5, No. 4, pp. 175-180, April. Islamabad Pakistan.

Robbins and Judge. 2008. Organizational Behaviour. Jakarta:Salemba Empat.

Sarwoko, Surachman, Armanu, dan Hadiwidjojo. 2013. Entrepreneurial Characteristics and Competency as Determinants of Business Performance in SMEs. IOSR Journal of Business and Management (IOSR-JBM. Volume 7, Issue 3 (Jan. - Feb. ), PP 31-38.

Spencer, Peter M., dan Spencer, Signe M. 1993. Competence at Work "Models for Superior Performance" . New York: Jhon Wiley \& Sons Inc.

Stoner, C.R. 1989. The foundations of business ethics: Exploring the relationship between organizational culture, moral values and actions. Advanced Management Journal, 54, 38 - 43.

Sutedi, A. 2009. Labor Law. Jakarta (ID): Sinar Grafika.

Sutrisno, Edy. 2011. Human Resource Management. Jakarta: Kencana Prenada Media Group.

Syahrum, Brahmasari, dan Nugroho. 2016. Effect of Competence Organization Culture and Climate of Organization to the Organizational Commitmen, Job Satisfactions and The Performance of Employess in The Scope of Makasar City Government.

Tominaga. 2013. Factors related to the intention to leave and the decision to resign among newly graduated nurses: a complete survey in a selected prefecture in Japan. Environ Health Prev Med. July; 18(4): 293-305

Walton, R. E. 1974. Quality of working life: what is it? Sloan Management Review, 15(1), 11-21.

Wayne A Lesko, 2003. Reading in Social Psychology: General, Classic, and Contemporary, Selection Fifth edition, United Stated of America. 
Xu, Anguo., dan Ye, Long. 2013. Impacts of Teachers' Competency on Job Performance in Research Universities with Industry Characteristics: Taking Academic Atmosphere as Moderator. Journal of Industrial Engineering and Management. JIEM, 2014 - 7(5): 1283-1292.

Yousaf, Sanders and Yustantio. 2016. Workplace Bullying and Intention to Leave: The Moderating Effect of the Organizational Commitment. The International Journal of Human Resource Management Volume 26. 